\title{
Using incentives sometimes means walking a very thin line: Bonusing as an economic development tool
}

\begin{abstract}
Stephen G. Hyndman
This paper examines the experience of attracting an international company to establish new operations to a location through government grants and subsidies. The author uses the deal reached between Stream International and the City of Belleville, Ontario, as a case study to develop an understanding of subsidies or bonuses, their nature, for what reasons they are sought, and in what context they are (or should be) awarded. While bonuses and subsidies are prohibited in Ontario, there is no limitation in law that precludes municipalities pursuing unconventional initiatives or applying unique solutions that create positive business climates as an incentive for new investment. Through an assessment of the legal, political and business implications, the author provides a greater understanding and reasonable and appropriate solutions to this common practice.
\end{abstract}

Keywords: incentives, investment attraction, Stream International, site selection

\section{Background}

In March of 2000, the City of Belleville became aware that a company known as Stream International ${ }^{1}$ was exploring the possibility of establishing a new operations centre somewhere in Canada. It was the City's understanding that Stream International's efforts had been focused on locations in Canada's eastern provinces.

Initially, municipal staff ascertained it was plausible that Stream International could find Belleville a suitable community in which to locate due to the nature of the company's labourforce requirements. A decision was made to actively pursue this company for the City of Belleville.

The President and Chief Operating Officer of Stream International confirmed that the company was exploring an eastern Canadian location. It was apparent, however, that one of the prime reasons the company was focusing on that part of Canada was the promise of sizeable grants or bonuses from various levels of Government, if Stream International was to establish its centre there.

\footnotetext{
${ }^{1}$ Stream International, headquartered in Canton, Massachusetts, is a company that provides a broad range of fully integrated eCRM services using voice, email, live chat and self-help technologies. Among its major clients are most of the largest and most successful hi-tech companies operating world-wide (both hardware and software firms). With centres located throughout the United States, Europe and Japan, Stream International was considered an aggressive growing in-bound call centre company that would be a strong asset to have in the community.
} 
The company expressed a willingness to entertain an Ontario location, but stated it required government support in the form of subsidies. The amount of subsidy was quantified during preliminary discussions with Stream International staff - the City was advised that Stream International, to consider Belleville as a location, would require a commitment to the equivalent of $\$ 4.0$ million (US), present value, in bonusing or other support, but that the company would be flexible on the ways such support could be structured.

Unlike the eastern provinces in Canada and many parts of the United States, the Provincial Government of Ontario has a policy of not providing grants or subsidies to any business to locate in Ontario. Further, Ontario municipalities are prohibited from bonusing ${ }^{2}$ to attract business. From Stream International's perspective, the fact that Ontario municipalities and the Provincial Government could not provide any form of subsidy or bonus seemed, at the outset, to be a significant disincentive to choose an Ontario location.

It was clear to municipal staff that to attract Stream International to Belleville, senior officials of Stream International would have to be convinced that the company would realize benefits equivalent to $\$ 4.0$ million (US) by locating in the City. Arguments were formulated on the basis that significant savings over the long term could be realized principally through the availability of a sizable and highly trained labour force within the Belleville area. The premise of the argument was that over time, the benefits derived by Stream International through the availability of this labour pool and the resulting savings through lower training costs and reduced staff turnover would be far more beneficial that an up-front one-time grant of \$4.0 million (US) from another jurisdiction that could not offer a comparable labour force.

Stream International officials felt strongly enough about the labour force argument to hold a job fair in Belleville over a two-day period in June 2000 to assess the quality and quantity of the labour force in the Quinte region to fill a 500 job centre. More than 2,500 persons registered at this fair, with more registering their interest through Stream's web site. What proved most important in the exercise was the level of qualification of the many who registered - Stream International officials noted that the Belleville experience was among the best of any area previously investigated. It became evident to senior personnel that there was a large, highly trained and capable labour force in the Belleville area that would service all the needs of Stream International. As a result of the successful job fair, Stream International's expectations for a centre in Belleville increased from 500 jobs to between 750 to 900 positions.

From that point forward in the recruitment process, the issue faced by the City of Belleville and Stream International officials became one of finding a suitable site. However, even though the case put forward by the City on the issue of labour force was proven, the issue of bonusing did not disappear.

\footnotetext{
${ }^{2}$ Section 111(1) of the Municipal Act of Ontario.
} 
Wage subsidy programs ${ }^{3}$ were available through Federal, Provincial and Municipal government agencies that could provide financial support to Stream International for those employees who met the qualifications of each of the programs. Initially, it was thought that upwards of twenty percent of all of Stream International's future employees could possibly qualify pursuant to one of these programs. Given the limitations of these programs, and using the twenty percent factor, even the most optimistic projections suggested Stream International would receive benefits in the order of $\$ 500,000$ to $\$ 750,000(\mathrm{Cdn})$ maximum, considerably less than the original $\$ 4.0$ million (US) which the company stated was necessary at the outset.

Based on the projected staff complement of 750 to 900 staff, the search for a suitable location was undertaken in earnest. It was determined that at least 80,000 square feet of building space would be required. There were essentially two possible locations:

- the unused portion of a building occupied by Nortel Networks; and

- a vacant building formally used by Zellers for a department store and IGA for a supermarket.

It is beyond the scope of this paper to describe in detail the negotiations that occurred between the principals of these two properties, the City of Belleville, and Stream International. Focus was eventually directed to the site containing the vacant building previously occupied by Zellers and IGA, both of which had vacated the site in favour of new facilities some years earlier. The building was structurally sound but required extensive restoration (including a new roof) to make it suitable for the call centre. Renovation costs for a call centre in this building were expected to be high (not unusual for call centres - tenant improvements, or TI's, are characteristically high for call centres).

At the point of finalizing a deal to lease this space to establish the call centre in the City of Belleville, Stream International officials sought an agreement from the City of Belleville to assist with the costs of renovating the existing building. Such an agreement, in their opinion, would enable Stream International to make a firm commitment to locate its centre in the City of Belleville.

\section{The deal}

The City of Belleville agreed to become involved financially. The deal negotiated between the City of Belleville and Stream International can be summarized as follows:

\footnotetext{
${ }^{3}$ These programs included the Targeted Wage Subsidy Program offered through Human Resources Development Canada, the Workfare program under the direction of the Provincial Government offered through the Hastings County Social Services Department, and the Job Connect program for youth offered under the direction of the Provincial Government through Loyalist College.
} 
- The City would invest $\$ 5.0$ million (Cdn) from its reserve accounts to acquire a substantial portion of the tenant improvements necessary to support occupancy by Stream International, and lease those improvements to Stream International over a ten-year period.

- The return on investment (ROI) was set at 5.5 per cent annually; this compared favourably to the 5 per cent return the City was earning on its reserve accounts. Payments would be made monthly over a ten-year period ( $\$ 53,931.85$ plus GST per month).

- The residual value of the tenant improvements (should the City be forced to sell the improvements) approximated $\$ 1.463$ million (many of the improvements would only have value for Stream International and hence would not bring any return on the open market). The City, as owner of the improvements, retained the right to repossess and sell the improvements in the event of default.

- The remainder of the City's capital investment, \$3.537 million, was secured through a letter of credit, declining over six years as the City recovered its investment.

- Stream International Inc., the parent to Stream International Canada (who is the tenant from a legal perspective) guaranteed the contract.

- The City registered its interests pursuant to the Personal Properties Security Act.

- RioCan Holdings Inc., owner of the premises, acknowledged the City's ownership rights to the tenant improvements and the right to enter the premises and repossess the improvements in its lease contract with Stream International Canada for the building.

- At the end of the ten-year lease, ownership of all tenant improvements would transfer to RioCan Holdings Inc.

It was the position of the President and Chief Operating Officer of Stream International and the Mayor of the City of Belleville that the involvement of the City from a financial perspective was a key factor in obtaining Stream International's commitment to locate its newest call centre in the City of Belleville.

\section{Purpose}

It is not uncommon for municipal economic development officers to be asked at the outset by representatives of firms looking for a new location whether bonuses or subsidies are available. This question is posed commonly by the principals of American firms who have had greater exposure to this form of economic development programming - receiving such a question from Stream International did not come as a surprise.

The purpose of this paper is to develop an understanding of subsidies or bonuses, their nature, for what reasons they are sought, and in what context they are (or should be) awarded. Using this information, the deal between Stream International and the City of Belleville will be assessed as 
a tool in securing Stream International's commitment to locate in the City of Belleville from the following perspectives:

- Whether the deal actually constituted a bonus or subsidy and if so, to what extent.

- The legal implications of such a deal, whether it was consistent with the meaning and intent of the Ontario Municipal Act.

- The political realities that resulted in the decision to invest and the political realities 'after the fact', to determine the political implications of investing in this fashion.

- The business perspective; the reasons that the deal was apparently so important to Stream International.

By doing so, it is hoped that in future when faced with similar circumstances, questions surrounding incentives and bonusing can be met with a greater level of understanding, and responded to in a manner that is reasoned and appropriate.

\section{Definition of a bonus or subsidy}

There is no simple definition or explanation of what constitutes a bonus or a subsidy - incentives can be found in many different forms. What may seem to be a bonus to one may not be considered as such by the next. So complex is the concept that it is not always simple to ascertain whether any specific action should be considered a bonus or subsidy.

The definition of subsidies has been a huge issue for those negotiating international trade agreements. Under international free-trade agreements including GATT and NAFTA, the definition of what should constitute a subsidy was paramount in the negotiations that preceded the formulation of these agreements. These agreements focused on implications for international trade but the complexities of defining what constituted a subsidy are nevertheless the same.

In real terms, subsidies can be as simple as giving an up-front one-time cash payment, or providing land or municipal services such as sewer or water services at a reduced or no cost, in consideration of certain benefits being provided by a firm in return (usually expressed as creation or preservation of jobs). Subsidies can also take the form of ongoing financial benefits, such as would be realized with tax incentives or holidays that would likely exist for some period of time. They can be less definite and very flexible, such as training allowances that are provided over a period of time subject to the application of conditions and eligibility requirements. Subsidies can also include such things as government purchase of goods or services.

Subsidies and bonuses can be disguised in quasi-financial ways. A loan guarantee in its own right may not cost the government money 'out-of-pocket' (unless of course the loan is called and 
default has occurred), but the firm receiving the loan guarantee would benefit in the form of lower interest rates or the availability of capital otherwise not within reach.

Subsidies can vary in amount - from relatively small amounts of money for each job created to many hundreds of thousands of dollars for each position created or saved. By way of example, noted below are a few of the better publicized agreements (LeRoy, 1994):

1. In 1992, the State of South Carolina granted German automaker BMW $\$ 150$ million (US) or roughly $\$ 79,000$ for each job created, which at that time the most costly automotive plant deal was made.

2. Indianapolis and Indiana agreed to a deal worth $\$ 294$ million (US) for United Airlines' new maintenance complex, or about $\$ 47,000$ per job.

3. In 1993, the State of Alabama gave German automaker Mercedes Benz $\$ 253$ million (US), or roughly $\$ 170,000$ for each job to be created.

4. The State of Illinois gave Sears located in Chicago bonuses worth $\$ 240$ million (US) just for staying in the community - even with the subsidy, Sears still reduced their employment levels.

5. The State of Kentucky gave Canadian steel maker Dofasco Inc. and Co-Steel Inc. $\$ 140$ million (US) for a 400 employee mini-mill, or roughly $\$ 350,000$ per job.

6. Reportedly, the Province of Nova Scotia and the Government of Canada provided $\$ 21.5$ million (Cdn) to EDS to establish a help-desk centre in Cape Breton, Nova Scotia for 900 jobs in the form of forgivable loans, training allowances and capital, at roughly $\$ 23,900$ per job.

It should be noted that often, the present value of incentives provided can vary considerably from the stated value of the incentive package. It is not uncommon that parts of incentive packages include services and benefits to be delivered in the future - the present value of such benefits therefore would be less than the stated amount. For example, the Kentucky deal in favour of Dofasco and Co-steel noted above reduces to $\$ 102,500$ per job from $\$ 350,000$ on a net present value basis as the majority of the benefits in this deal will be earned as tax credits over a 25 -year period (Wiewel et al, 1995).

Not all subsidies or bonuses benefit only the company to which the monies are directed; consider the value of an up-front cash payment to a firm as compared to the same amount of money invested in employee training. Training allowances may be worth considerable to a firm, but from the municipal perspective, money invested in employee training provides community benefits in the form of a more-highly trained labour force that has greater transferability potential and enhances the attractiveness of the community to other investors. 
Some argue that some inducements should not be considered subsidies or bonuses at all. Governments usually bear the responsibility for education - the granting of special training in support of a particular industry is certainly an incentive, but is it a bonus or subsidy? Consider the perspective that if a training allowance is granted, such training:

- benefits the employee;

- benefits the community; and

- perhaps should be regarded as the responsibility of the government in the first instance.

A plausible argument could be made that training allowances are not subsidies, or if they are should not be valued at an equivalent rate to their actual cost.

Another complicating issue is the difference in taxation systems between jurisdictions. Some jurisdictions tax machinery while other jurisdictions do not; the question arises as to whether the jurisdiction that does not tax machinery should be considered to be giving a bonus or subsidy. In those jurisdictions, all firms would receive the same benefit, as all would be treated alike.

The critical element in determining the existence of a bonus or subsidy in all of the examples given above is that of a definable benefit being realized by a firm that is not, as a right, available to other firms within the same jurisdiction.

At risk of over-simplifying the matter, and in light of the foregoing, for the purposes of this paper it would appear that bonuses or subsidies would have to possess the following characteristics:

- government provided - there is a measurable expense to government in exchange for certain benefits (usually investment or jobs);

- can involve the contribution of money, other assets (such as land), or services (such as training allowances or loan guarantees);

- goes to a specific firm but which is not as a right available to all firms operating within the same jurisdiction; and

- firm receiving gets a measurable financial benefit or gain.

\section{The stream deal - bonus or not?}

If Stream International had not secured the deal with the City, the obvious alternative available to Stream International would have been to borrow the money needed to finance the tenant improvements on the open market, and repay the funds over time. It is not possible to ascertain precisely the interest rate that would have been required in the market to borrow $\$ 5.0$ million (Cdn) to finance the tenant improvements, but for analysis purposes, an assumption can be made 
that a rate of 8.5 per cent would not have been unreasonable. On the basis of these parameters, the deal with the City for Stream equates to a present value savings of \$590,617 (Cdn). For the purposes of this paper, it will be assumed that the benefits to Stream International equate to $\$ 590,000(\mathrm{Cdn})$ present value.

From the City's perspective, there is no cost, and in fact a slight profit compared to what was being earned on these funds at the time of the deal. The present value of the increased return over the 10 years would amount to $\$ 110,883$. Given that the capital was fully secured by virtue of the combination residual value of the tenant's improvements and letter of credit, the risk to the City was comparatively low. (What the City was risking was its return on investment, or the opportunity cost of $\$ 5.0$ million ( $\mathrm{Cdn}$ ) at five per cent annually over ten years - but of course the City would have had the jobs and the increased assessment to offset this risk.)

The deal appears to be a wise investment for Stream International, and from a business perspective a positive investment for the City. But does the deal constitute a bonus or subsidy? Clearly the deal was a good business proposition for Stream International - Stream benefited to the extent of $\$ 590,000$. If one were to assume that the City would not be prepared to make such an investment as a matter of course with other firms, then perhaps from the perspective of Stream International it was a bonus. But at the same time, there was no cost to the City and in fact the City realizes a modest profit. From the City's perspective, because the City obtained significant benefits at no cost, it would have given no bonus because there was no cost. Clearly from the City's perspective it provided an incentive, but it did not provide a subsidy or bonus.

This reinforces the suggestion made earlier in this paper that defining subsidies is not an easy task. In this instance, it would seem the meaning of what occurred depends on the perspective of the onlooker.

\section{The role of subsidies}

There is a sizable body of literature that argues the entire idea of subsidies is flawed ${ }^{4}-$ the concept of subsidies supporting economic development is an abyss to which there is no bottom. These arguments are based on the premise that when one jurisdiction grants a subsidy, others must respond in turn. The granting of one subsidy implies that another is there for the asking. Once a subsidy is provided to one company, the next company can argue for the same (and should expect no less). The opponents of subsidies argue that once the principle of granting bonuses or subsidies is established, bonuses or subsidies can spiral out of control.

\footnotetext{
${ }^{4}$ There are many articles published arguing that subsidies should be abolished in the United States for a wide variety of reasons. An article written by Robert Guskind, The Giveaway Game Continues provides an overview of the debate. The publication Do State \& Local Tax Incentives Work? written by Robert G. Lynch also provides considerable insight to this argument.
} 
The issue of where the money comes from to finance subsidies also arises. Municipalities or regional jurisdictions that have more wealth and a greater access to capital would seem to have the advantage over other (and perhaps smaller and less affluent) jurisdictions without the same access to capital. Invariably, it is those smaller and less affluent jurisdictions that most need the benefits of renewed economic development activity that subsidies might play a part in bringing. The money to finance incentives comes from taxpayers; where subsidies are granted, taxes of competing businesses would go to support a competitor. Proponents would argue that the economic benefits of the new investment will repay the subsidy and hence over time there is no cost to the taxpayer - in fact, the taxpayer would profit.

Through all of this, the key question becomes a simple one - is it right for regional jurisdictions or municipalities to use taxpayers money to purchase jobs? The answer to this question is not, however, as simple.

It is argued as well that subsidies often fail to achieve their intended objectives. Rent controls were established to ensure apartments remained affordable - many will argue that this form of subsidy in support of renters has had the opposite effect, as rent controls have caused a decline in the number of new rental units being built. This has reduced the supply relative to demand, and as a result has increased the cost of rent relative to the quality of the accommodation available. And governments are finding that it is exceedingly difficult to get out of rent controls now that they provide them.

The question of what role subsidies play is an interesting one. In simple terms, it can be said that subsidies are used to overcome a deficiency, a shortcoming that may exist in one jurisdiction relative to competing jurisdictions. In this instance, subsidies would be the great equalizer. But as noted earlier in this paper, the State of Illinois and the City of Chicago provided huge subsidies in support of business investment, and Illinois can hardly be considered an area whose economy or economic potential is at a disadvantage. In the case of an economy that is as competitive as any, what role are subsidies expected to perform; what purpose are subsidies expected to achieve?

Subsidies are intended to overcome a shortcoming, but in reality, the shortcoming never goes away. The purpose of a subsidy therefore, in theory, must be to reduce or eliminate the financial impact of the shortcoming over time. Economically, the subsidy in this instance would really represent the present day value of the stream of costs over the projected life of the investment that would accrue due to the shortcoming.

But this perspective on the role and purpose of subsidies is too simple, and does not adequately describe the role and purpose of subsidies used throughout the world today. Three ${ }^{5}$ theories are

\footnotetext{
${ }^{5}$ Four theories are proposed in this work but two are very similar and are combined for purposes of this paper. The author sees these theories as flawed in his work, but are described here to define why subsidies are supported by some and demonstrate the complexities at work in the application of subsidies.
} 
put forward as the basis for supporting subsidies as a means of spurring economic activity and generating jobs (Lynch, 1996). They are:

- cost of production argument;

- business climate argument;

- $\quad$ supply side argument.

\section{Cost of production argument}

The cost of production argument applies when a subsidy is used in a manner that reduces an ongoing cost that the company would otherwise have to pay, which then affects the cost of production (thereby making the company more competitive).

A municipal tax bill is an example of a cost that affects the cost of production to which subsidies sometimes are applied to offset. When a jurisdiction provides a subsidy in the form of elimination or reduction in taxes, it is argued that such an incentive is applied to the cost of production, essentially reducing the cost of production and making the company more profitable or competitive as a result. It is further argued that the higher the taxes, the higher the cost of doing business and hence the lower the profits. With projected lower profits, firms would be less likely to invest in such a jurisdiction, and in the extreme, could choose to relocate from an area without such incentives to one that provides such incentives. It is suggested, therefore, that providing incentives that lower the ongoing costs of production (in this instance, reducing taxes) will create more business activity and indirectly create jobs.

Those who oppose the concept of incentives note that in reality, at the local level, taxes are comparatively a small portion of the total costs of doing business for most firms. It is generally regarded in the literature that taxes are a small part of the cost of doing business and hence, they are not the most important factors affecting business investment decisions. Generally it is accepted that the key factors business decision makers consider when assessing different locations include (Lynch, 1996, p 22):

- cost and quality of labour;

- proximity to markets for output;

- access to raw materials and supplies;

- access to quality transportation networks and infrastructure;

- quality of life (schools, higher education, health, recreation, low crime, housing);

- utility costs. 
By way of example, consider that an enterprise with upwards of 850 employees could be assessed an annual tax bill (for municipal purposes only) in the order of $\$ 750,000$ - by comparison, this same firm paying wages averaging $\$ 17$ per hour plus benefits would find their annual payroll costs likely exceeding $\$ 30.0$ million. Even a 50 per cent reduction in municipal taxes would be, by comparison, very small relative to labour costs alone, and even less significant when considering the total cost of operating the business.

It has been shown through studies conducted in the United States that after all deductions are made, state and local taxes paid by the average business represents less than two per cent to three per cent of all costs (Lynch, 1996, p 4). Therefore, even with the commitment of a local municipality to reduce taxes significantly over an extended period of time, opponents argue that there would be very little meaningful impact on the cost of production created by a reduction in municipal taxes.

\section{The business climate argument}

The premise of the business climate argument is that a good business climate encourages economic activity and is conducive to economic well-being and job creation, and that providing bonuses or incentives to business creates a positive business climate. It is argued that businesses will relocate to, expand or remain within communities with favourable business climates, and that the availability of incentives is an important component of creating a favourable business climate.

There is merit in the argument that communities or regions with favourable business climates can achieve economic development success as a result. But what is meant by a favourable business climate?

Business climate is linked to a community's reputation in the business community for being accommodating and responsive to the needs of business. A community that understands the needs of business, and in turn structures its service delivery policies and programs and tax structure to reflect the needs of business creates a favourable business climate. Proponents of the business climate theory argue that incentives can improve a community's business climate by demonstrating the willingness of the community to acknowledge the needs of business and step forward periodically with funds necessary to maintain a competitive advantage for local business.

The business climate argument is based on the assumption that business decision makers will base decisions on perceptions as well as hard facts. Those who oppose the concept of incentives argue that most business decision makers are not greatly influenced by perceptions. It is argued that good business climates are created through the level and the quality of services provided, 
and if incentives are given at the expense of providing a high level of service, there would be a resulting decline in the business climate.

It has been shown that communities with good service infrastructure and a highly educated or trained workforce, and a high quality of life for its inhabitants (low crime rates, excellent schools, state of the art health care facilities) are generally regarded as having the best business climates. It is interesting to note that in some cases, communities with very high tax rates are considered to have good business climates because of the high level and quality of services provided and the quality of life afforded its residents.

Opponents to tax incentives argue that they undermine the ability of governments to raise adequate revenues to pay for many of the key services that are necessary to attract businesses to the community. They argue that by giving away taxpayers money to individual firms, in order to maintain a low tax rate, reduction in service is necessary. A reduction in services, in their view, results in a decline in the business climate.

For an example of this, one can look to the State of California where a limit on investment in infrastructure maintenance and enhancement in the past has led to a decline in infrastructure quality that ultimately hurt business. The business climate in parts of California is very poor, due in part to issues surrounding the deregulation of the power industry in the State, but due also to the failing infrastructure caused by the failure of governments to invest in maintenance and upgrading of the infrastructure that services business.

It would appear that lower costs do not necessarily translate directly into positive business climates, and higher costs do not necessarily translate into negative business climates.

\section{The supply side argument}

The supply side argument is based on the premise that incentives by means of tax cuts for individuals and businesses provide incentives for working and increased savings, leading to increased consumption and investment, thereby stimulating economic activity. In essence, this theory argues that tax cuts for individuals promote increased work because individuals are able to keep more of what they earn. Tax cuts also allow individuals to save more money and thus make more funds available for consumption and business investment that in turn creates economic activity. From the business perspective, proponents argue that tax incentives raise the profitability of businesses receiving the benefit and as such stimulate their willingness to invest more in the community, thereby creating new economic activity.

Opponents of the supply side argument suggest that the proponents have tended to exaggerate the positive effects of tax cuts on the work ethic resulting in higher savings. Economists suggest tax 
cuts have negligible impact on work ethic and in reality lead to very small increases in savings, and that any increased consumption resulting from such initiatives is not assured within the same economic community. In the case of businesses, opponents argue that increased profitability does not necessarily mean that the increased profits generated would be reinvested in the same community to increase economic activity.

It is clear from these theories that the roles of subsidies can vary depending on circumstances and the needs of the community and the benefiting firm. In simple terms, it is easy to acknowledge that if anybody is given money up-front or on an ongoing basis in exchange for certain otherwise profitable actions, the person receiving that money would profit as a result. How people use the money and perform their obligations will determine whether those providing the payment receive what they wanted, in return. It would appear subsidies are, in a manner, a form of investment from which, in many cases, there is no guarantee of a return.

\section{Legal perspective}

Municipalities in Ontario are considered to be a creature of the Province, and can only carry out those duties or actions that are specifically assigned to them by Provincial statute. One of the most significant statutes that regulate the actions of municipalities is the Ontario Municipal Act.

The Municipal Act addresses the issue of municipalities granting bonuses or subsidies in favour of private business. Section 111(1) of the Municipal Act states:

Despite any general or special Act, a council shall not assist directly or indirectly any manufacturing business or other industrial or commercial enterprise through the granting of bonuses in aid thereof, and, without restricting the generality of the foregoing, the council shall not grant assistance by,

(a) giving or lending any property of the municipality, including money;

(b) guaranteeing borrowing;

(c) leasing or selling any property of the municipality at below fair market value;

(d) giving a total or partial exemption from any levy, charge or fee.

The only exception to this clause would be policies established under a community improvement plan adopted pursuant to the Ontario Planning Act $^{6}$ and approved by the Provincial Minister of Municipal Affairs. In the instance of the deal with Stream International, a community improvement plan was not in existence.

\footnotetext{
${ }^{6}$ Under the Planning Act, the Minister of Municipal Affairs and Housing has been approving community improvement plans throughout Ontario that provide for the giving of grants or subsidies to private land owners under certain circumstances - the most common applications in Ontario are for façade improvement programs. It is unlikely the Minister, under current Provincial practice, would approve a community improvement plan that would permit grants such as those given in the examples provided earlier in this paper, as a tool to entice investment in a community.
} 
The City of Belleville was careful not to structure its investment as a loan, which clearly is prohibited by the provisions of the Municipal Act. The City structured the deal as an investment in property that was acquired by the City to be leased to Stream International over a ten-year period. The concept of municipalities purchasing property for resale or leasing in support of economic development is not unique - many municipalities acquire land and develop industrial parks for eventual resale or lease. There is nothing in the statutes that suggests that only land can be acquired and sold or leased - the Act allows the leasing of assets provided the transaction is at market value.

The issue therefore is not the right of the City to lease the property. The issue from a legal perspective is whether the deal was in keeping with the provisions of the Municipal Act with regard to fair market value.

Courts have determined that leasing property for a nominal amount does constitute a bonus, but in this instance the agreement between the City and Stream International could not be construed as nominal. An article written in 1989 that appeared in a 1989 special lecture series 'Recent Developments in Municipal Law, ${ }^{7}$ by Robert A. Blackwell, Q.C., who at the time was the solicitor for the City of London, noted that with regard to the issue of market value:

(a) A court would likely construe the section narrowly with the benefit of the doubt to the municipality.

(b) Dealings of any kind between a municipality and a business or industry, even those involving the giving, lending, or the leasing or selling below market value of municipal property, the guaranteeing of borrowing or the relieving against levies, charges or fees, are not absolutely prohibited by subsection 12(1), only where 'aid' or 'assistance' accrues to the business or industry by reason of the municipality receiving in return insufficient or no consideration, whether in money or kind.

While the deal may have been a wise transaction for Stream International from strictly a financial perspective, the same can also be said for the City. The City's approach ensured that it would receive a return on its investment higher than it would have if the deal had not been done. In other words, Stream International received the benefits of the deal but the City received a beneficial return on its investment. It cannot be argued therefore that the City committed to give some of its resources to a private company, as it did not - the City obtained a full and profitable return for its investment.

${ }^{7}$ From a legal opinion provided by Robert J. Ord, Solicitor for the City of Belleville. 
From a legal perspective, there does not appear to be any issue - it would seem the deal is not in conflict with the provisions of the Ontario Municipal Act. Whether, however, the deal would be within the intent of what Section 111(1) was supposed to do is perhaps another matter.

\section{Political perspective}

Through the 1990's, economic development became a key issue for the City of Belleville. This perhaps is true for most municipalities in North America due to the recession of the early 1990's. In Belleville, there were a number of specific factors from the perspective of the Mayor and Council as to why economic development required considerable attention. By the late 1990's, these included:

- There had been no new plant or major new employer locate in the City of Belleville since the late 1980's.

- In 1999, Nortel Networks decided to close its manufacturing facility in Belleville and lay off over 1,000 people. $^{8}$

- The unemployment rate throughout most of the late 1990's hovered around 10 per cent, considerably higher than for the Province of Ontario as a whole. At the beginning of 1998, the unemployment rate was 11.6 per cent ${ }^{9}$ when the rate for Ontario as a whole was 7.6 per cent.

- Substantial numbers of persons employed in Belleville were doing one or two part-time jobs and desperately wanted full-time permanent positions. It was felt the unemployment rate actually was considerably higher than that published by Human Resources Development Canada - certainly, there was considerable under-employment which was not reflected in published statistics.

In the late 1990's, while the recession of the early 1990's had come to a close, no appreciable recovery had taken place in the City of Belleville. Most of the manufacturing companies in Belleville were doing reasonably well but there was no new activity within the community. The perspective was that the City was doing relatively poorly in attracting new investment. Council knew that Eastern Ontario was generally considered the poor cousin in Ontario and lagged behind the rest of Ontario with historically higher unemployment rates, but Belleville City Council was committed to changing this trend.

Throughout 1998 and 1999, City Council focused specifically on the needs of the City with regard to economic development. The City's Economic Development Advisory Committee interviewed local industrial leaders and held strategy sessions involving industry and the

\footnotetext{
${ }^{8}$ Nortel Networks did close its manufacturing operation but converted the former industrial complex to a research and development centre handling the world market for their Meridian telephone systems. This centre now employs approximately 500 persons.

${ }^{9}$ This figure is published by Human Resources Development Canada and applies to economic region 515 which encompasses the City of Belleville, as well as the rest of Hastings County, Prince Edward County, Frontenac County, Renfrew County, and the County of Lennox \& Addington.
} 
business community at-large; participation was high. The objective of these initiatives was to determine the specific actions that should be undertaken to address the major economic problems of the City.

Out of these sessions emerged a number of specific conclusions and recommended actions. One of the most condemning conclusions was the City of Belleville was considered by the investment community as a very poor community in which to invest. In other words, the City of Belleville did not provide a positive business climate.

To tackle this problem, the City decided to create a new development services department combining the roles of economic development, planning, approvals, and building. In Council's eyes, the concept of a one-window approach to managing development and growth would ensure City departments did not operate at cross-purposes (as they had in the past), and as a result create a more positive business climate. Another initiative to improve the performance of the City was to develop strong links with regional economic development organizations and join the Quinte Area Economic Development Commission (QAEDC). Together, the new Development Services Department and the QAEDC would be mandated to resolve the issues that plagued the City in its inability to attract new investment.

With these actions underway, Council knew it needed to show positive results. The opportunity presented to the City by Stream International had the potential of being just the result it needed to justify its actions. To City Council, landing Stream International would have represented proof of the City's success in dealing with economic development.

Stream International was not the first opportunity that came to the City after it initiated a new approach to economic development. There were other positive benefits resulting from Council's initiatives, including decisions by Bioniche Life Sciences and Sigma Stretch Film to locate in the City of Belleville. However, due to the numbers of potential jobs Stream International could bring to the City, Council saw this opportunity as one it had to win.

The desire to be victorious was elevated as a result of another competition that had been waged earlier in 2000. Great Dane had expressed interest in locating a trailer assembly plant employing 500 persons in Ontario, and particular attention had been directed to the Quinte region. The City of Belleville pursued this company vigorously, and while the company did decide to locate in the Quinte region, it selected a site in the neighbouring municipality of Quinte West. Feeling that the City had lost the campaign to attract Great Dane, Council felt great pressure to succeed in its pursuit of Stream International.

The decision of Stream International to hold a job fair was a major breakthrough in the City's pursuit of this business. However, by so doing, the public became aware of Stream 
International's interest in this community. As a result of the tremendous success of the job fair and the positive comments made by the President and Chief Operating Officer of Stream International about the City of Belleville, the public quickly developed a strong expectation that Stream International would commit to locate in the City. So strong were the comments made by Stream International personnel that the public's perception became that Stream International was Belleville's to lose.

Behind closed doors, City Council was aware that Stream International had decided to locate in Belleville provided it could find a suitable location. The issue was not whether Belleville was a suitable location but rather, whether an appropriate building could be found. Council knew that it had won the fight for Stream International, but that the victory would be very hollow indeed if Stream International was unable to find a suitable site at an appropriate cost.

City Council took an aggressive stance, determining that the City could not be seen doing anything less than everything within its power to win. Council knew the public expectation was that Stream International was coming. There were over 2500 job applicants, many of whom were unemployed or underemployed, waiting anxiously for the decision to be made. Council was under tremendous pressure, and knew it had to do whatever it took to meet the needs of Stream International. From a political perspective, Council had no choice but to attempt to respond positively to any demand put forward by Stream International.

Negotiations between Stream International and owner of the preferred site became challenging over the issue of tenant improvements (which as noted previously is a significant cost in call centre development and is often a stumbling block). The building had been empty for some years and needed to be renovated to accommodate the call centre. Costs were high, and senior officials of Stream International presented this problem to the Mayor of the City of Belleville - Stream International wanted and needed assistance from the City. Negotiations proceeded, and Stream International gave a commitment to Council that if the deal as set out previously in this paper was made available, Stream International would commit to locate their facility in the City of Belleville.

Council's justification for doing this deal was as follows. The City of Belleville, like many other cities, had invested in land and services to ready industrial land to accommodate the needs of new industry. Such investments were usually costly, and when considering the time value of money, the City rarely obtained any return on investment - in many cases, the City likely lost money. And it was noted that such investments were purely speculative, that there was no guarantee as to when or even if the City would realize any economic gain from such an investment. With Stream International, the City would invest in a different kind of asset but would do so knowing that it had its capital secured, that it would receive a return on investment at a rate competitive with the return the City was obtaining on its current investment, and most 
importantly, there was nothing speculative about the investment - the jobs would come if the money was invested. Council saw this investment as far superior to any investment it could have made in acquiring and pre-servicing additional industrial land.

Stream International did make the decision to locate in Belleville following the confirmation of the deal by City Council, much to the delight of the community. However, the local media did not report the deal in a manner that enabled many in the community to understand what had transpired - this perhaps was understandable given the complexity of the transaction. There were many in the community that believed that the City of Belleville had simply given $\$ 5.0$ million to Stream International; even more than six months following the announcement of the deal, there are still some in the community who do not understand that the City invested in the development and is receiving a return on its investment. The deal became an issue during the 2000 election campaign, and while not a decisive factor, the community did elect a new Mayor and three members of Council.

From a political perspective, little by little Council was boxed in by events that in part were beyond its control; politically, Council perhaps had no choice but to do the deal. In the final analysis, the community won the development, and the City actually profited as well. It would seem the most critical problem that arose was that the nature of the deal was not communicated to the community in a manner that was understood. Perhaps better communication would have improved the public's understanding of what was transpiring. But it is also important to recognize that negotiations also involved private business interests that would not benefit by public exposure.

\section{Analysis}

From the perspective of the law and common understanding of what constitutes a bonus or subsidy, the deal between the City of Belleville and Stream International was not a form of bonusing.

But the deal was critically important to Stream International. There is a financial benefit to Stream International each year over the ten years of the lease agreement, but as a percentage of the total cost of establishing the call centre and doing business for ten years, the benefits derived from the deal are comparatively small. The present value of the benefit to Stream International has been estimated at $\$ 590,000$, but the present value of 10 years of just wages alone for 1400 employees (using an average of $\$ 15$ per hour) would exceed $\$ 430$ million - the bonus is less than two-tenths of one percent of the cost of labour. If labour is the critical issue for call centres, and Belleville proved its worth from a labour perspective, certainly a financial bonus of such a small magnitude would do little to influence the final location decision. 
Literature supports the premise that in most cases, incentive packages do not alter the final location decisions. Only when two competing areas are exactly the same might the incentive package have any significant influence. The question arises as to whether Stream International would have elected to come to Belleville if City Council had not approved the deal. It would seem from a financial perspective, not having the deal would have had no impact; in other words, the cost of production argument in support of bonuses would not have applied in this instance.

The key issue is related to the issue of business climate. As noted previously, proponents argue that subsidies or bonuses create a positive business climate. It would seem therefore, that since the President and Chief Operating Officer of Stream International stated that the deal was important in the final decision to locate in the City of Belleville, the reasons would be related to business climate.

It is apparent that Stream International received a number of benefits from the deal in addition to the financial package. The City of Belleville had sold itself to Stream International based on the available labour force, and had clearly stated its great desire to have this company locate in Belleville. As with any new venture, there is always a risk. The fact that the City of Belleville was willing to invest of itself in the project was a clear statement to the senior officials of Stream International of the City's confidence in its own arguments and that the City was committed to the success of the company in Belleville. The City would have a stake in the success of Stream International in Belleville - it would have an obligation to live up to the claims it had made in selling the City as the premiere location for this centre. From the perspective of Stream International, there was a partnership of sorts between the City and the company, both sharing the same goal of success.

In reviewing the three theories in support of subsidies described previously, in each case the benefits derived by Stream International as a result of the deal demonstrate merit: the savings on an annual basis would provide a very modest reduction in the cost of production; the business climate created was positive; and Stream International's decision to expand ${ }^{10}$ the call centre in Belleville supports the supply side argument pointing to the prospect of additional investment by the company in the community. But it would appear the business climate argument is the most important in this instance.

It has been the experience of many communities including Belleville that new businesses tend to locate in areas where the founder lived or according to the geographical preferences of some of the top executives. At times, personalities and local contacts are significant factors in location decisions. When such personal factors are brought into play, incentives likely play a very small

\footnotetext{
${ }^{10}$ In January 2001, Stream International announced that the new call centre in Belleville would be expanded to approximately 1400 jobs, through the leasing of the former IGA floor space in the building in which Stream International is located. Among the comments made by the President of Stream International on the occasion of announcing the expansion was the strong support received from the local community and the excellence of the local labour force.
} 
role in the decision-making process from a financial perspective, but they can contribute to the creation of a business climate that secures the support of top executives. Stream International became aware of the City of Belleville through a local contact ${ }^{11}$, but the City had to prove itself in order to be considered - and the willingness of the City to invest in the project appears to have been a key factor in obtaining Stream International's commitment to locate in Belleville.

\section{Conclusions}

Conventional wisdom in Ontario is that bonuses or subsidies cannot be given to any private business. That fact is true - the Municipal Act clearly states that bonusing is prohibited. But there is no limitation in law that precludes municipalities pursuing unconventional initiatives or applying unique solutions that create positive business climates as an incentive for new investment.

Many perceive the Stream International deal as a financial package. Even those who negotiated the deal regarded it as such in the beginning. It was felt that the deal should be considered in no broader context than the financial perspective. If that were true, strictly on the financial grounds the deal would appear to be a non-issue. But it appears the deal was much more important, and more important for non-financial reasons. The positive climate that developed because of Belleville's willingness to commit in a meaningful way to the project obviously played a role in the ultimate decision by Stream International to locate its call centre in Belleville. Now that Stream International has expanded the operation to employ more than 1400 , the benefits of the City's initiative to invest in tenant improvements have paid greater dividends than was ever anticipated.

Clearly, the dismissal of incentives as an inappropriate tool in support of business development in any particular community or region is not appropriate. It would appear, notwithstanding the negative arguments that can be brought forward as to why incentives are not an effective economic development tool, economic and social reasons can exist in certain circumstances to refute negative criticisms and actually support the premise that incentives are a necessary part of doing business.

It is important to accept that imaginative problem solving is key to successful competition in the global economy. Competition has reached unprecedented proportions - looking at your neighbouring community as your principal competitor for economic development has been replaced with the threat posed by communities in other countries thousands of kilometres away. The payoff for being imaginative and not following conventional wisdom, as demonstrated by the Stream International and City of Belleville example, is clear. And, while some will argue

\footnotetext{
${ }^{11}$ A local business-person who was related to one of Stream International's senior officials became aware of the company's interest in Canada, and alerted the City of Belleville to this opportunity accordingly. This individual played a key role in supporting the City's initiative towards attracting this firm to the community.
} 
still that the City should not have invested as it did, it is difficult to criticize any initiative when there are no losers.

It is critical that municipalities be careful and diligent. There is risk, certainly a financial risk, if an incentive package includes any form of investment. Imaginative solutions must be applied appropriately, and not all propositions are worthy of support. Traditionally, willingness to apply a unique solution to one situation implies the same deal will be available to the next - this is a particularly serious matter for municipal corporations. But unique problem solving cannot work in this manner. Not everything is equal, nor should everything be expected to be. In each case, a full and careful assessment of the benefits, risks and costs is needed before any decisions should be entertained.

And that speaks to the serious shortcoming of the approach employed by the City in support of Stream International - the inability of municipalities to be consistent or to appear to treat all equally. While perhaps successful in this instance, the deal entered into by the City of Belleville is not without its detractors. In dealing with Stream International, the City managed to walk across a very deep canyon on a very thin rope and successfully reach the other side. The problem for the City, now that it decided to cross the first canyon, is that there are even more and deeper canyons ahead. Turning back is not an option, and moving across more canyons is sure to lead to even more treacherous ground. Interestingly enough, as successful as this deal has been for both Stream International and the City of Belleville, it has also created a political dilemma for the City that is not easily managed. ${ }^{12}$

\section{Author's biography}

Stephen Hyndman assumed his current position with the City of Belleville as its Director of Development Services in January, 2000. In this role, he is responsible for a broad range of services pertaining to growth and investment, including economic development services, land use planning, development approvals, and building approval procedures. Stephen obtained a degree in Environmental Studies from the University of Waterloo in 1975 and a diploma in Urban Land Economics from the University of British Columbia in 1997. As a full member of the Canadian Institute of Planners, he has successfully brought the disciplines of planning and economic development together to promote excellence in community development. Stephen was one of the key members of the team that brought Stream International to the City of Belleville.

\footnotetext{
${ }^{12}$ Following announcement of the Stream International deal, other local businesses expressed interest in obtaining a similar agreement with the City. In response, municipal staff began to develop a policy on use of this technique in the future, which was proving to be a difficult task. Prior to this policy being finalized, the municipal election in late 2000 resulted in defeat of the incumbent mayor - the incoming candidate had campaigned that agreements similar to that entered into with Stream International were not advisable. In light of this change in the political structure, these local businesses, at least for the time being, appear to have abandoned their plans.
} 


\section{Bibliography}

Bartik, Timothy J., Economic Development Incentive Wars, W.E. Upjohn Institute for Employment Research, Kalamazoo MI, Spring 1995.

Colgan, Charles S., Commentary - Brave New World: International Regulation of Subsidies and the Future of State and Local Economic Development Programs, Economic Development Quarterly, Vol 9 No. 2, May 1995.

Fisher, Peter S. and Alan H. Peters, Industrial Incentives - Competition among American States and Cities, W.E. Upjohn Institute for Employment Research, Kalamazoo MI, 1998.

Guskind, Robert, The Giveaway Game Continues, Planning Magazine, February 1990.

Hahn, Kurt, When and When Not to use Incentives to Attract Business or to Retain Existing Business, Government Finance Review, 1996.

LeRoy, Greg, No More Candy Store - States and Cities Making Job Subsidies Accountable, Federation for Industrial Retention and Renewal, Chicago Ill. And Grassroots Policy Project, Washington D.C., 1994.

Lynch, Robert G., Do State and Local Tax Incentives Work?, Economic Policy Institute, Washington D.C., 1996.

Research \& Development Branch, Planning Services Division, Alberta Municipal Affairs, Municipal Development Incentives for Private Developers - A Review and Evaluation of Land Use Incentives, 1988.

Schriner, James A., Using Economic Development Incentives as a Marketing Tool, Economic \& Technology Development Journal of Canada, 1997.

Wiewel, Wim, Joseph Persky and Daniel Felsenstein, Are Subsidies Worth It? How to Calculate the Costs and Benefits of Business Incentives, Government Finance Review, October 1995. 